\title{
Bond Strength Between Resin Cement to High-Translucency Zirconia Following Sandblasting And Non-Thermal Plasma Treatment
}

Resistência de união entre cimento resinoso e zircônia de alta translucidez após tratamento de jateamento e plasma não térmico

Daniele Oliveira da SILVA ${ }^{1}$, Tabata Prado SATO ${ }^{1}$, Marina Bacelar SILVA ${ }^{1}$, Letícia Grilo de SOUZA ${ }^{1}$, Eduardo Shigueyuki UEMURA ${ }^{1}$, João Mauricio Ferraz da SILVA ${ }^{1}$

1 - São Paulo State University (Unesp), Institute of Science and Technology, São José dos Campos, Department of Dental Materials and Prosthodontics, São José dos Campos, SP, Brazil.

\begin{abstract}
Objective: The aim of this study was to compare the bond strength of High-Translucency zirconia (HT) and lithium disilicate dental ceramics, under different surface treatments. Material And Methods: For this, ceramics were divided into groups: Control Group (C) $(n=5)$, lithium disilicate sheets, conditioned with $10 \%$ hydrofluoric acid, followed by application of $37 \%$ phosphoric acid, silane and universal adhesive application; Group HTAI ( $=5$ ), HT zirconia sheets were blasted with silica oxide, followed by the application of universal adhesive; Group HTPAI ( $n=5)$, HT zirconia sheets were blasted with silica oxide, followed by the application of non-thermal plasma and universal adhesive and the HTP Group ( $\mathrm{n}=5$ ), HT zirconia received only the application of non-thermal argon plasma. Subsequently, the specimens of each group were subjected to a cementation process with resin cement, obtaining cylinders. After 24 $\mathrm{h}$ of storage, in distilled water, at $37^{\circ} \mathrm{C}$, the specimens were subjected to a mechanical micro-shear test. The data obtained were submitted to ANOVA One-way followed by the Tukey test (5\%). Results: The HTP Group was excluded from the statistical analysis, as adhesions failed within the storage period. In addition, it was not possible to verify a statistical difference between the control group $\mathrm{C}$ and the experimental groups HTAI and HTPAI. Conclusion: The results showed that the applicability of high translucency zirconia can potentially be compared to the lithium disilicate bond strength, when submitted to the same surface treatments, except for the plasma application, which alone was not effective.
\end{abstract}

\section{KEYWORDS}

Lithium disilicate; Nonthermal plasma; Zirconia ceramic.

\section{RESUMO}

Objetivo: O objetivo deste estudo foi comparar a resistência adesiva das cerâmicas dentárias de zircônia de alta translucidez e dissilicato de lítio. Materiais e Métodos: Para isso, cerâmicas foram divididas em grupos: Grupo Controle (C) (n = 5), lâminas de dissilicato de lítio, condicionadas com ácido fluorídrico 10\%, seguido de aplicação do ácido fosfórico 37\%, aplicação de silano e aplicação do adesivo universal; Grupo HTAI ( $\mathrm{n}=5$ ), lâminas de zircônia HT foram submetidas ao jateamento com óxido de sílica, seguido da aplicação do adesivo universal; Grupo HTPAI ( $n=5$ ), lâminas de zircônia HT foram submetidas ao jateamento com óxido de sílica, seguido da aplicação do plasma não térmico e do adesivo universal e o Grupo HTP $(n=5)$, lâminas de zircônia HT receberam apenas a aplicação do plasma não térmico de argônio. Posteriormente, os espécimes de cada grupo foram submetidos a um processo de cimentação com cimento resinoso, obtendo-se cilindros. Após 24h, de armazenamento em água destilada a $37^{\circ} \mathrm{C}$, os espécimes foram submetidos a ensaio mecânico de microcisalhamento. Os dados obtidos foram submetidos à ANOVA 1-fator seguido pelo teste de Tukey (5\%). Resultados: O Grupo HTP foi descartado da análise estatística, pois as adesões falharam dentro do período de armazenamento. Além disso, não foi possível verificar diferença estatística entre o grupo controle C e os experimentais HTAI e HTPAI. Conclusão: Os resultados mostraram que a aplicabilidade das zircônias de alta translucidez pode potencialmente ser comparada à resistência adesiva da cerâmica de dissilicato de lítio, quando submetidas aos mesmos tratamentos de superfície, com exceção da aplicação de plasma, que isoladamente não foi efetiva.

\section{PALAVRAS-CHAVE}

Dissilicato de lítio; Plasma não térmico; Zirconia cerâmica. 


\section{INTRODUCTION}

$\mathrm{D}$ ental restoration aesthetics, particularly the translucency of modern restorative materials, is an important concern to the current perspectives in dentistry [1]. For this, protocols, plans and techniques are constantly developed and improved, associating resistance, durability, biocompatibility, aesthetics and bond strength, increasing the results predictability $[2,3]$.

In this sense, dental ceramics offer favorable qualities for oral rehabilitation such as biocompatibility, resistance to chemical degradation, mechanical resistance, low conductivity and thermal diffusivity $[4,5]$. These materials, considered inorganic and non-metallic, are obtained by heating raw minerals, under high temperatures [4] and can be classified according to their microstructure [6], processing technique [7] and susceptibility to surface acid degradation, according to the degree of degradation with hydrofluoric acid [8].

From this, Lithium disilicate ceramics arise as one of the mostly used restorative material, due to its advantages and prospective yielding clinical data [9]. This ceramic presents high values of bond strength and is composed of a silica matrix and lithium oxide $\left(\mathrm{Li}_{2} \mathrm{O}\right)$ crystals [10], for this reason, it was chosen as the control group of this study.

In order to improve the resistance properties, developments of ceramic materials with the incorporation of zirconia, showed significant increase in flexural strength [11]. These polycrystalline compounds were presented as monophasic ceramics sintered from a dense polycrystalline structure [7,12-14]. However, these systems were highly opaque [15], which might limit the esthetic of restorations [15], such as In Ceram material, consisting of a mixture of $69 \%$ alumina oxide $\left(\mathrm{Al}_{2} \mathrm{O}_{3}\right)$ and $31 \%$ zirconium oxide $\left(\mathrm{ZrO}_{2}\right)$, mainly indicated for single or multiple restorations in the posterior region of the oral cavity $[16,17]$.

In order to improve the esthetic properties, the translucency of polycrystalline zirconia were improved by developing a high translucency zirconia (HTZ), under pressure-assisted densification [18]. In this case, translucency is the optical ability between opacity and transparency and for a restoration this behavior - light transmitted and reflected - must be similar to the natural tooth. Thus, the improved translucency, although inferior to glass ceramic, refine aesthetic without a significant reduction in flexural strength [19]. Optical properties improvement can be obtained due processing techniques, that can reduce and shape zirconia particles [20]. For this, studies are important to compare the strength of these materials with actual bonding procedures.

Regarding the different protocols of the surface treatments, necessary procedure before cementation to improve the quality of bonding [21], hydrofluoric acid attack is a procedure for feldspar, leucite-reinforced and lithium disilicate ceramics and $\mathrm{Al}_{2} \mathrm{O}_{3}$ sandblasting for glassinfiltrated aluminum oxide, zirconium-reinforced and densely sintered, aluminum oxide ceramic [22]. HTZ is an acid resistant material and several types of surface treatment can be used [23], such as $\mathrm{Al}_{2} \mathrm{O}_{3}$ sandblasting, silica [24], alumina [25] or plasma application [26,27], described as the fourth state of matter and the final result of the energy increase of a solid system [28], besides that, as an alternative treatment for polycrystalline materials, the nonthermal plasma application [29-31] can increase reactivity [32,33] without affecting surface roughness of the ceramic [30].

Therefore, the purpose of this study was to compare the bond strength of resinous cement to high translucency zirconia and to lithium disilicate ceramic, under different surface treatments. In this context the null hypothesis was that the different surface treatments do not influence the adhesion strength.

\section{MATERIAL AND METHODS}

\section{Materials}

In the present study, two types of ceramics were used and are described in Table 1. 
Table I - Ceramic materials used as experimental e control groups.

\begin{tabular}{|c|c|c|}
\hline Material & Manufacturer & Composition \\
\hline Highly translucent zircônia $(\mathrm{HT})$ & Amann Girrbach & $\begin{array}{c}\mathrm{ZrO}_{2}+\mathrm{HfO}_{2}+\mathrm{Al}_{2} \mathrm{O}_{3} \text { and } \\
\text { other oxides }\end{array}$ \\
\hline Lithium disilicate (DS) & Ivoclar & $\begin{array}{c}\mathrm{SiO}_{2}+\mathrm{Li}_{2} \mathrm{O}+\mathrm{K}_{2} \mathrm{O}+\mathrm{MgO} \\
+\mathrm{Al}_{2} \mathrm{O}_{3}+\mathrm{P}_{2} \mathrm{O}_{5}\end{array}$ \\
\hline
\end{tabular}

\section{Obtaining specimens}

Twenty ceramic sheets were made: 5 of lithium disilicate (E-Max - Ivoclar Vivadent Ltda - Tambore/Barueri/SP), where blocks of DS ceramic were sectioned on the ISOMET 1000 PRECISION SAW (BUEHLER - Lake Bluff llinoisUSA), obtaining sheets of $0.7 \mathrm{~mm}$ thickness and 15 of Highly translucent zirconia Zolid FX (Amann Girrbach Brasil Ltda - Curitiba - Paraná) frameworks were obtained through milling a solid block using CAD/CAM procedures and either of two systems in the EXOCAD software, and in the sequence by the SIRONA, also in the thickness of $0.7 \mathrm{~mm}$.

After the obtaining, all ceramic sheets were polished, in order to eliminate irregularities on their surface and to standardize their measurements in $0.5 \mathrm{~mm}$ of thickness and 1 $\mathrm{cm}$ of diameter, simulating an ultrafine ceramic laminate. This process was carried out manually with the gradual increase of the sandpaper granulation (50-180). Afterwards, the ceramic sheets were included in a PVC cylinder, to which was added chemically activated acrylic resin, observed in Figure 1.

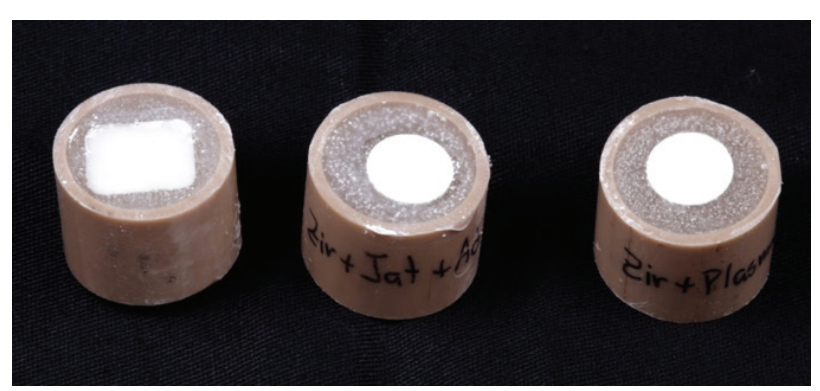

Figure 1- Ceramic sheets included in acrylic resin for obtaining specimens.
Subsequently, the specimens were distributed into a control group and three experimental groups:

- Control Group ( $\mathrm{n}=5$ ) (Figure 2): DS sheets received conditioning with 10\% hydrofluoric acid $(20 \mathrm{sec})$, washing with air / water spray for $1 \mathrm{~min}$, application of $37 \%$ phosphoric acid (1min), washing again with air/water spray (30 sec), drying with air (1 min), application of two consecutive layers of silane (Monobond N - Ivoclar Vivadent) with an applicator tip (Micro-Brusch) (30 sec each), application of the universal adhesive (Tetric $\mathrm{N}$ Bond - Ivoclar Vivadent) also with the applicator tip (Micro-Brusch) (1 min) and, finally, the total evaporation of the solvent.
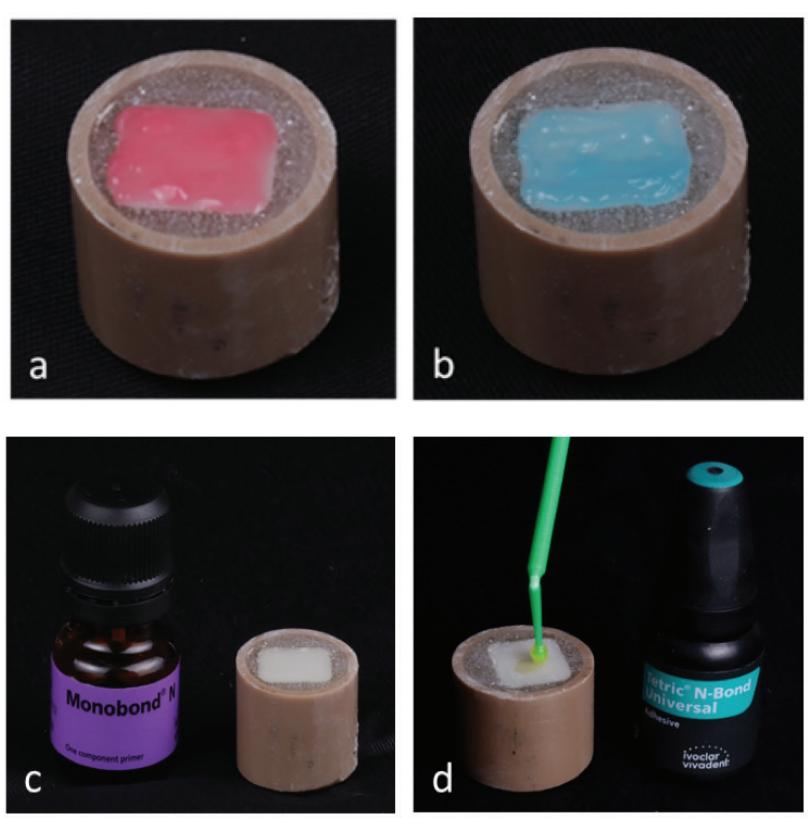

Figure 2 - Surface treatment of the Control Group: a) application of hydrofluoric acid; b) application of phosphoric acid; c) application of silane; d) application of the universal adhesive.

- HTAl Group ( $\mathrm{n}=5$ ) (Figure 3): HT sheets were blasted with silica oxide $(5 \mathrm{sec})$ at 2 $\mathrm{cm}$ of distance, followed by a universal adhesive application (Tetric N - Bond Universal - Ivoclar Vivadent). 


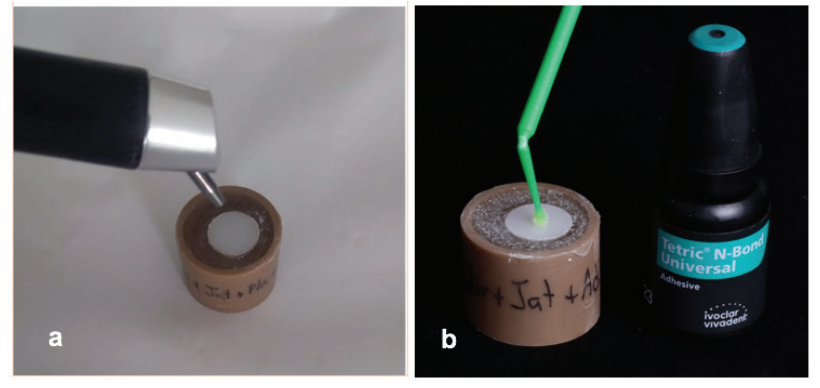

Figure 3 - Surface treatment of the HTAI Group: a) Sandblasting with silica oxide and b) application of the adhesive.

- GRUPO HTPAl (n = 5) (Figure 4): HT sheets were sandblasted with silica oxide $(5 \mathrm{sec})$ at $2 \mathrm{~cm}$ of distance, followed by application of non-thermal argon plasma ( $1 \mathrm{~min}$ at $10 \mathrm{~mm}$ ), followed by application of the universal adhesive (Tetric N Bond Ivoclar Vivadent ).
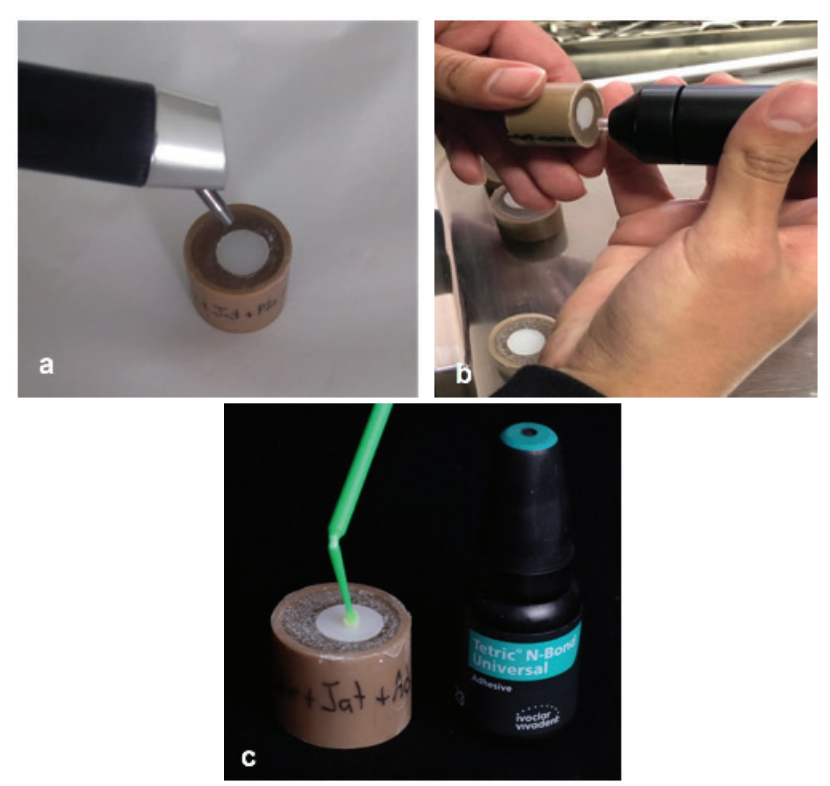

Figure 4 - Surface treatment of the HTPAI Group: a) Sandblasting with silica oxide; b) application of non-thermal argon plasma and c) adhesive application.

- GRUPO HTP ( $n=5)$ : HT sheets received only application of non-thermal argon plasma for $1 \mathrm{~min}$ at $10 \mathrm{~mm}$ of distance.
The equipment used for the plasma application was the Surface Plasma model SAP (Surface - Engenharia e Soluções de Plasma LTDA, Campinas, SP, Brazil), at room temperature $\left(22^{\circ} \mathrm{C}\right)$. Argon gas was used at flow rate of $1 \mathrm{~L} / \mathrm{min}$. (Praxair 4.8, White Martins Gases Ind. S. A., Rio de Janeiro, RJ, Brazil), which generates a $20 \mathrm{~mm}$ plasma beam, applied vertically.

\section{Microshear test}

For the micro-shear test preparation of the specimens, "spaghetti" noodles were used, which have an external diameter of $2 \mathrm{~mm}$ and an internal diameter of $0.8 \mathrm{~mm}$. They were cut to a height of $2 \mathrm{~mm}$ and positioned on the ceramic sheets, delimiting the adhesion area. The light-curing resin cement Variolink Esthetic was applied inside these tubes, until its complete filling and photoactivated for $40 \mathrm{~s}$ (Figure 5).
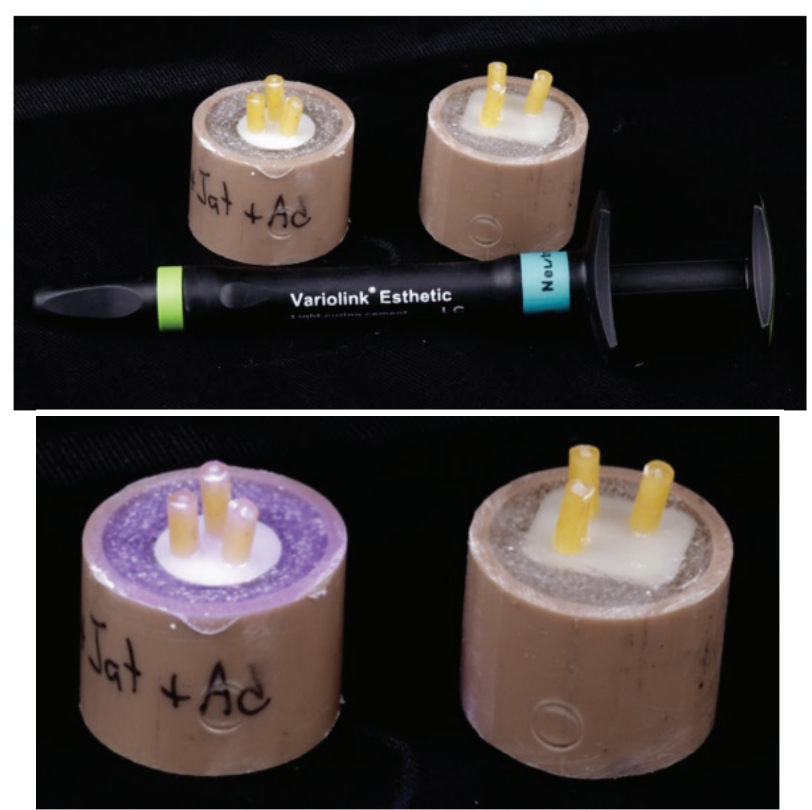

Figure $\mathbf{5}$ - Cementation of cylinders with resin cement on ceramic sheets. 
Three tubes were cemented in each ceramic sheet, thus obtaining 15 adhesions per group. Then, they were stored in distilled water, at $37^{\circ} \mathrm{C}$, for $24 \mathrm{hs}$. After that period, the pasta tubes were carefully removed, to avoid any stress to the composite.

After removing the tubes, the specimens were subjected to a Microshear test, that was performed on an EMIC DL2000 universal testing machine with a $50 \mathrm{~kg}$ load cell.

A metallic base was used, which allows the correct position of the specimens and an orthodontic wire of $0.2 \mathrm{~mm}$ in diameter fixed on the upper movable end of the machine (Figure 6).

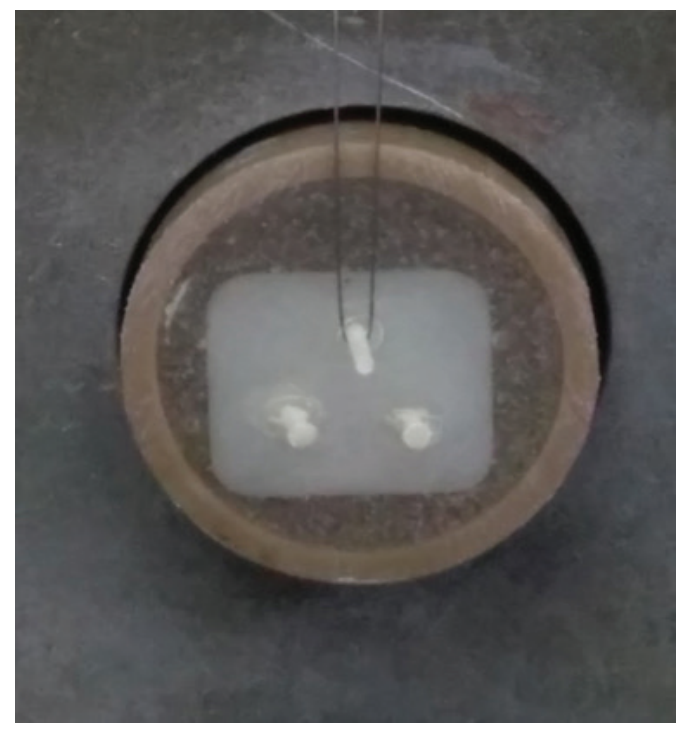

Figure 6 - Specimen positioned for microshear test.

In carrying out the test, the wire forms a loop around the composite resin cylinder, positioned at the adhesive interface. The speed used was $0.5 \mathrm{~mm} / \mathrm{sec}$.

The micro shear resistance value was determined by the quotient of the maximum force applied during the test, by the area used for adhesion. This value, expressed in $\mathrm{MPa}$, determines the load required to break the bond strength, between ceramic and resin cement.

\section{Statistical analysis}

The data obtained were analyzed statistically, using parametric descriptive statistics, one-way ANOVA and Tukey's (5\%) pairwise multiple comparisons.

\section{RESULTS}

At the storage period in distilled water, all specimens in the HTP group failed adhesively, so the group did not participate of the statistical analysis. The results of the statistical analysis using the ANOVA 1 factor performed with the control group and the experimental groups HTAl and HTPAl are shown in Table 2.

Table 2 - Results from ANOVA statistical analysis.

\begin{tabular}{|c|c|c|c|c|c|}
\hline & SS & DF & MS & F(DFn,DFd) & Pvalue \\
\hline Treatment (between columns) & 10,84 & 2 & 5,420 & $\begin{array}{c}F(2,39)= \\
0,3539\end{array}$ & $p=0,7042$ \\
\hline Residual (within columns) & 597,3 & 39 & 15,32 & & \\
\hline
\end{tabular}

The means between groups C (6.69 \pm 5.12), HTAl (7.39 \pm 2.81$)$ and HTPAl (7.93 \pm 3.44) did not present a statistically significant difference ( $\mathrm{p}=0.7042)$, as seen in Figure 7.

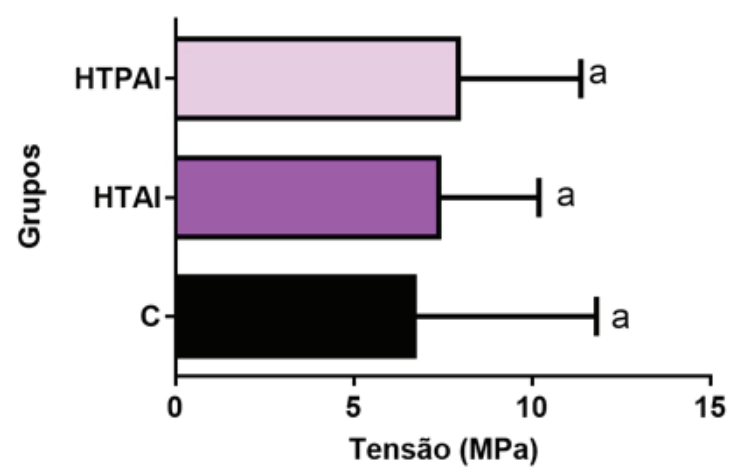

Figure 7 - Analysis of micro-shear results.

\section{DISCUSSION}

The current scenario of dentistry presents a large amount of different indirect restorative materials, with differentcompositions and surface 
treatments [22], and create demands that justify this study that compared the bond strength of high translucency zirconia and lithium disilicate ceramics to the resinous cement. The analysis performed aimed scientifically support clinical choices for protocols of ceramic restorations, favoring the longevity of these materials [34].

Under the limitations of an in vitro study, the absence of statistical difference between control $(6,69 \pm 5,12)$ and experimental groups $\operatorname{HTAl}(7,39 \pm 2,81)$ and HTPAl $(7,93 \pm 3,44)$ demonstrates that the bond strength behavior of high translucency zirconia, under specific surface treatments, and lithium disilicate ceramics are similar. These results are corroborated by several studies that focused on obtaining an adhesive cementation with a zirconia restoration $[35,36]$.

In order to reduce marginal microleakage and to increase the adhesion to dentin and enamel, resin-based cement is the conventional luting material of choice [37]. An in this context, polymerization efficiency is imperative for clinical success. The light transmission transmittance of the curing light through - is responsible for the conversion degree results [38] and in order to overcome the limits towards bonding procedures, HTZ improved translucency and optical properties allowing to obtain an aesthetic material $[39,40]$.

Regarding the nonthermal plasma application an increase of surface reactivity was expected as a result of plasma ions interaction with electrons [31]. Using this type of treatment, this study, in agreement with previous research [27], showed that it was only possible to find significant values of bond strength, for high translucency zirconia, in association with another treatment, the sandblasting. This might be due to the fact that zirconia surface treated with aluminum oxide abrasive presents an imperative roughness, micro-retentions, that increases the contact area for cement bonding [41,42]. And in this sense, argon plasma is a process that not significantly change the roughness pattern of the material and because of its cold procedure characteristic, also there is not a significant risk of zirconia phase transformation [31].

\section{CONCLUSION}

Based on the results obtained and the limitations of this study, it is possible to conclude that highly translucent zirconia and lithium disilicate ceramics present present similar behavior for the bond strength, when subjected to especific surface treatments, although it is not recommended the non-thermal plasma application for highly translucent zirconias, as a single treatment.

\section{Conflict of interest}

The authors have no proprietary, financial, or other personal interest of any nature or kind in any product, service, and/or company that is presented in this article.

\section{REFERENCES}

1. Duminis T, Shahid S, Karpukhina NG, Hill RG. Predicting refractive index of fluoride containing glasses for aesthetic dental restorations. Dent Mater. 2018;34(5):e83-e8. doi:10.1016/j.dental.2018.01.024

2. Ahmadl.Protocols for predictable aesthetic dental restorations: Oxford: John Wiley \& Sons; 2008.

3. MizrahiB. Aesthetic and biomechanical precision in complex cases. Alpha Omegan. 2009;102(4):142-7. doi:10.1016/j.aodf.2009.10.005

4. Anusavice KJ. Degradability of dental ceramics. Adv DentRes. 1992;6:82-89. doi:10.1177/08959374920060012201

5. Denry I, Holloway JA. Ceramics for dental applications: a review. Materials. 2010;3(1):351-68.

6. McLarenEA, Cao PT. Ceramics in dentistry-partl: classes of materials. Inside dent 2009;5(9):94-103.

7. Shenoy A, Shenoy N. Dental ceramics: an update. JConserv Dent. 2010;13(4):195-203. doi:10.4103/0972-0707.73379

8. Valandro LF, Della Bona A, Antonio Bottino M, Neisser MP. The effect of ceramic surface treatment on bonding to densely sintered alumina ceramic. JProsthet Dent. 2005;93(3):253-9. doi:10.1016/.jprosdent.2004.12.002

9. Kern M, Sasse M, Wolfart S. Ten-year outcome of three-unit fixed dental prostheses made from monolithic lithium disilicate ceramic. J Am Dent Assoc. 2012;143(3):234-40. doi:10.14219/jada.archive.2012.0147

10. Aboushelib MN, Sleem D. Microtensile bond strength of lithium disilicate ceramics to resin adhesives. J Adhes Dent. 2014;16(6):547-52. doi:10.3290/j. jad.a33249

11. Pilathadka S, VahalováD, Vosáhlo T. The Zirconia: a new dental ceramic material. An overview. Prague Med Rep. 2007;108(1):5-12. 
12. Kobayashi K, Kuwajima H, Masaki T.Phase change and mechanical properties of ZrO2-Y203 solid electrolyte after ageing. Solid State lonics. 1981;3-4:489-93. doi:https://doi.org/10.1016/0167-2738(81)90138-7

13. Tsukuma K, Ueda K, Shimada M. Strength and Fracture Toughness of Isostatically Hot-Pressed Composites of Al203 and Y203-PartiallyStabilized Zr02.J Am Ceram Soc. 1985;68(1):C-4-C-5. doi:https://doi. org/10.1111/j.1151-2916.1985.tb15251.x

14. Tsukuma K, Shimada M. Strength, fracture toughness and Vickers hardness of Ce02-stabilized tetragonal Zr02 polycrystals (Ce-TZP). J Mater Sci. 1985;20(4):1178-84.doi:https://doi.org/10.1007/BF01026311

15. Manicone PF, Rossi lommettiP, Raffaelli L. An overview of zirconia ceramics: basic properties and clinical applications. J Dent. 2007;35(11):819-26. doi:10.1016/j.jdent.2007.07.008

16. Raut $\mathrm{A}, \mathrm{Rao} \mathrm{PL}$, Ravindranath T.Zirconium for esthetic rehabilitation: an overview. Indian JDent Res. 2011;22(1):140-3. doi:10.4103/0970-9290.79979

17. SchmittJ, Wichmann M, Karl M, Göllner M, Lohbauer U, HolstS. Surface characteristics of zirconia-based posterior restorations: clinical and scanning electron microscopic analysis. J Can Dent Assoc. 2011;77:b31.

18. Casolco SR, Xu J, Garay JE. Transparent/translucent polycrystalline nanostructuredyttria stabilized zirconia with varying colors. Scripta Materialia 2008:58(6):516-9.

19. DangraZ, Gandhewar M. The use of newer high translucency zirconia in aesthetic zone. Case Rep Dent. 2014;2014:432714. doi:10.1155/2014/432714

20. Church T. Translucency and strength of high translucency monolithic zirconium oxide materials. United States: MEDICAL GROUP SAN ANTONIO; 2016.

21. Della Bona A, Anusavice KJ, Hood JA. Effect of ceramic surface treatment on tensile bond strength to a resin cement. Int J Prosthodont. 2002;15(3):248-53.

22. Soares CJ, Soares PV, Pereira JC, Fonseca RB. Surface treatment protocols in the cementation process of ceramic and laboratory-processed composite restorations: a literature review. J Esthet Restor Dent. 2005;17(4):224-35. doi:10.1111/j.1708-8240.2005.tb00119.x

23. Alves M,Campos F, Bergoli CD, Bottino MA, Özcan M, Souza R. Effect of adhesive cementation strategies on the bonding of Y-TZP to human dentin. Oper Dent. 2016;41(3):276-83. doi:10.2341/15-052-L

24. May LG, Passos SP,Capelli DB, Ozcan M, Bottino MA, Valandro LF.Effect of silica coating combined to aMDP-based primer on the resin bond to Y-TZP ceramic. JBiomed Mater Res B Appl Biomater. 2010;95(1):69-74. doi:10.1002/jbm.b.31684

25. Tsuo Y, Yoshida K, Atsuta M. Effects of alumina-blasting and adhesive primers on bonding between resin luting agent and zirconia ceramics. Dent Mater J. 2006;25(4):669-74. doi:10.4012/dmj.25.669

26. Valverde GB, Coelho PG, Janal MN, Lorenzoni FC, Carvalho RM, Thompson VP, et al. Surface characterisation and bonding of Y-TZP following non-thermal plasma treatment. JDent. 2013;41(1):51-9. doi:10.1016/j.jdent.2012.10.002

27. de Mendonça BC, Negreiros WM, Giannini M. Effect of aluminum oxide sandblasting, plasma application and their combination on the bond strength of resin cement to zirconia ceramics. Braz Dent Sci. 2019;22(2):275-80.

28. Eliezer S, Eliezer Y.The fourth state of matter: an introduction to plasma science. 2nd Ed.:Boca Raton:CRCPress; 2001.
29. Shimizu H,Inokoshi M, Takagaki T,Uo M, Minakuchi S. Bonding efficacy of 4-META/MMA-TBB resin to surface-treated highly translucent dental zirconia. J Adhes Dent. 2018;20(5):453-9. doi: 10.3290/j.jad.a41330.PMID:30375581.

30. da Silva BTF, Trevelin LT, de Sá Teixeira F, Salvadori MC, Cesar PF,Matos AB. Non-thermal plasma increase bond strength of zirconia to a resin cement. Braz Dent Sci. 2018;21(2):210-9. doi: https://doi.org/10.14295/bds.2018.v2ti2.1562.

31. Vilas Boas Fernandes Júnior V, Barbosa Dantas DC, Bresciani E, Rocha Lima Huhtala MF. Evaluation of the bond strength and characteristics of zirconia after different surface treatments. J Prosthet Dent. 2018 Dec;120(6):955-9. doi: 10.1016/.jprosdent.2018.01.029. Epub 2018 Jun21.PMID:29935728.

32. Lopes BB, Ayres APA, Lopes LB, Negreiros WM, Giannini M. The effect of atmospheric plasma treatment of dental zirconia ceramics on the contact angle of water. Appl Adhes Sci. 2014;2(1):17.

33. Pozzobon JL, Pereira GKR, Wandscher VF, Dorneles LS, Valandro LF. Mechanical behavior of yttria-stabilized tetragonal zirconia polycrystalline ceramic after different zirconia surface treatments. Mater Sci Eng C Mater Biol Appl.2017 Aug 1;77:828-35. doi: 101016/.jmsec.2017.03.299. Epub 2017 Apr 4. PMID:28532098.

34. Soares CJ,Giannini M, Oliveira MT, Paulillo LA, Martins LR. Effect of surface treatments of laboratory-fabricated composites on the microtensile bond strength to a luting resin cement. J Appl Oral Sci. 2004 Mar;12(1):45-50. doi: 10.1590/s1678-77572004000100009. PMID:21365151.

35. Özcan M,Bernasconi M. Adhesion to zirconia used for dental restorations: a systematic review and meta-analysis. J Adhes Dent. 2015 Feb;17(1):7-26. doi: 10.3290/j.jad.a33525.PMID:25646166.

36. Aboushelib MN, Kleverlaan CJ, Feilzer AJ. Selective infiltration-etching technique for a strong and durable bond of resin cements to zirconia-based materials. J Prosthet Dent. 2007 Nov;98(5):379-88. doi:10.1016/S00223913(07)60123-1.PMID: 18021827.

37. Gu XH, Kern M. Marginal discrepancies and leakage of all-ceramic crowns: influence of luting agents and aging conditions. Int J Prosthodont. 2003 MarApr;16(2):109-16. PMID: 12737239.

38. Turp V, Sen D, PoyrazogluE, Tuncelli B, Goller G. Influence of zirconia base and shade difference on polymerization efficiency of dual-cure resin cement. $J$ Prosthodont.2011Jul;20(5):361-5. doi:10.1111/.j.1532-849X.2011.00721.x. Epub 2011May 31.PMID:21627708.

39. Sulaiman TA, Abdulmajeed AA, Donovan TE, Ritter AV, Lassila LV, Vallittu PK, etal. Degree of conversion of dual-polymerizing cements light polymerized through monolithic zirconia of different thicknesses and types. J Prosthet Dent 2015 Jul;114(1):103-8. doi:10.1016/.jprosdent.2015.02007. Epub2015 Apr 14. PMID:25882969.

40. Zhang Y.Making yttria-stabilized tetragonal zirconia translucent. Dent Mater. 2014 0ct;30(10):1195-203. doi:10.1016/.jdental.2014.08.375. Epub2014 Sep2. PMID:25193781;:PMCID:PMC4167579.

41. Sarmento HR, Campos F, Sousa RS, Machado JP, Souza RO, Bottino MA, etal. Influence of air-particle deposition protocols on the surface topography and adhesion of resin cement to zirconia. Acta Odontol Scand. 2014 Jul;72(5):34653. doi: 10.3109/00016357.2013.837958. Epub 2013 0ct31. PMID:24175663.

42. Rosen MR. From treating solution to filler surface and beyond. The life history of a silane coupling agent. Coatgs technol. 1978;50(644):70-82.

Tabata Prado Sato (Corresponding address)

Av. Dr. Eng.Francisco Jose Longo, 777, Jd. Sao Dimas

Sao Jose dos Campos, Brazil.

E-mail: tabata.sato@unesp.br

Date submitted: 2020 Jun 03

Accept submission: 2020 Aug 24 
